\title{
ANAK DAN RUANG BERMAIN: TELAAH TERHADAP BEBERAPA PENELITIAN BERBASIS AFFORDANCES
}

\author{
John Fredy Bobby S. \\ Architecture Department, Faculty of Engineering, Binus University \\ Jl. K. H. Syahdan No. 9, Palmerah, Jakarta Barat 11480 \\ bsaragih@binus.edu
}

\begin{abstract}
Children's response towards something is different from adults'. If an architect designs the foot of a monument with a beautiful arch, a child will respond it as a slide. When an architect designs a water pool as an aesthetic element of a monument area, a child will respond with a different return, which is a place to shower/swim and play, not for aesthetic. What is this phenomenon? And how can we understand this well? This story reassures us that between adults and children have different concepts of a building or space. With a descriptive approach to literature review, this article examines some affordance-based studies. From the few studies presented, it appears that affordances are not enough to understand why kids play on an informal play space. Semiotic approach can help to better understand why children play in informal spaces.
\end{abstract}

Keywords: children, play, affordances, semiotics

\begin{abstract}
ABSTRAK
Kemampuan anak merespon sesuatu berbeda dari orang dewasa. Jika arsitek mendesain kaki tugu dengan lengkungan yang indah, anak akan meresponnya sebagai 'prosotan'. Bila arsitek mendesain kolam air sebagai elemen estetis dari sebuah kawasan tugu, anak kembali meresponnya dengan berbeda, yaitu sebagai tempat untuk mandi/berenang dan bermain, bukan untuk keindahan. Fenomena apa ini? dan bagaimana kita dapat memahami ini dengan baik? Kisah di atas semakin meyakinkan kita bahwa antara manusia dewasa dan anak mempunyai konsep yang berbeda terhadap sebuah bangunan atau ruang. Dengan pendekatan kajian pustaka secara deksriptif, artikel ini menelaah beberapa penelitian yang berbasis affordances. Dari beberapa penelitian yang dipaparkan, terlihat bahwa affordances tidaklah cukup untuk memahami mengapa anak bermain pada ruang bermain informal. Pendekatan semiotika dapat membantu untuk lebih memahami anak bermain di ruang informal.
\end{abstract}

Kata kunci: anak, bermain, affordances, semiotika 


\section{PENDAHULUAN}

Anak-anak di taman tugu pahlawan Surabaya menjadikan kolam yang mengitari museumnya sebagai tempat mandi dan bermain. Kaki tugu yang besar dan melengkung malah dijadikan perosotan (Salmina W. Ginting dan Nurlisa Ginting, 2002). Isu dari pernyataan ini berfokus pada satu hal: ruang bermain, sebuah fenomena yang sering menjadi perbincangan hangat di masyarakat, dan Pemerintah/ Pengelola kota adalah pihak yang sering di jadikan sebagai pihak tertuduh. Tak salah, karena memang Undang-undang No.23 tahun 2002 tentang Perlindungan anak sangat jelas mengurai tentang bermain sebagai hak anak (pasal 11) dan ruang bermain sebagai fasilitas yang harus disediakan oleh Pemerintah (pasal 56).

Di satu sisi, upaya untuk memenuhi kebutuhan ruang bermain sudah dilakukan oleh pemerintah, salah satu di antaranya adalah dengan mengeluarkan standar atau peraturan tata kota yang mengatur tentang dimensi, jarak dan lokasi tertentu. Walaupun demikian, fakta memperlihatkan, tidak semua teritori kota, khususnya di Indonesia, mempunyai ruang bermain yang cukup untuk memenuhi kebutuhan bermain anak-anak. Gejala minimnya ruang bermain semakin diperparah dengan adanya upaya perubahan fungsi lahan, yang awalnya ruang terbuka berubah menjadi ruang terbangun. Sementara itu ruang bermain pada komplek perumahan banyak ditinggalkan anak-anak.

Ternyata fenomena tersebut tidak hanya terjadi di Indonesia. Seymour Gold, seorang peneliti bidang bermain dan rekreasi (dalam Joyce Laurens, 2005) mengungkap hasil penelitiannya mengenai tendensi rekreasi dalam tingkat perumahan yang ada di California. Ditemukan bahwa banyak taman bermain dalam komplek perumahan yang tidak terpakai. Clare Cooper (dalam Joyce Laurens, 2005) mengatakan bahwa banyak anak justru menyukai saat-saat bermain dalam periode yang pendek, seperti di antara pulang sekolah dan waktu makan, atau sebelum makan malam, mereka bermain di lapangan kosong di sekitar rumah, di depan rumah atau di trotoar muka rumah, anak-anak tentu tidak bodoh untuk pergi jauh ke taman bermain hanya untuk bermain sejenak.

Apa yang disampaikan di atas memperlihatkan bahwa umumnya masyarakat cenderung untuk melihat ruang bermain sebagai ruang fisik yang terstandarisasi, baik dari segi posisi, ukuran, permukaan, dll. Sehingga tak salah bila isu minimnya ruang bermain bahkan pada beberapa kasus mubazirnya ruang bermain menjadi sorotan. Pemikiran tersebut terus berkembang hingga saat ini.

Gambar 1 memperlihatkan fenomena anak bermain di ruang yang tidak semestinya mereka gunakan. Bahkan tak jarang media massa menyindir secara lebih tajam lagi melalui publikasi beberapa gambar yang lebih ekstrim yang memperlihatkan fenomena anak bermain pada tempat-tempat yang selayaknya tidak digunakan sebagai tempat bermain oleh mereka. Pertanyaan yang timbul adalah: Bagaimana anak membentuk ruang bermainnya? Bagaimana ruang yang terbentuk mampu diyakini sebagai ruang bermain? apa yang menarik dari ruang tersebut yang 'menghipnotis' anak untuk memanfaatkannya? atau kita sebagai manusia dewasa yang mempersepsikan berbeda dengan anakanak tentang ruang bermain?
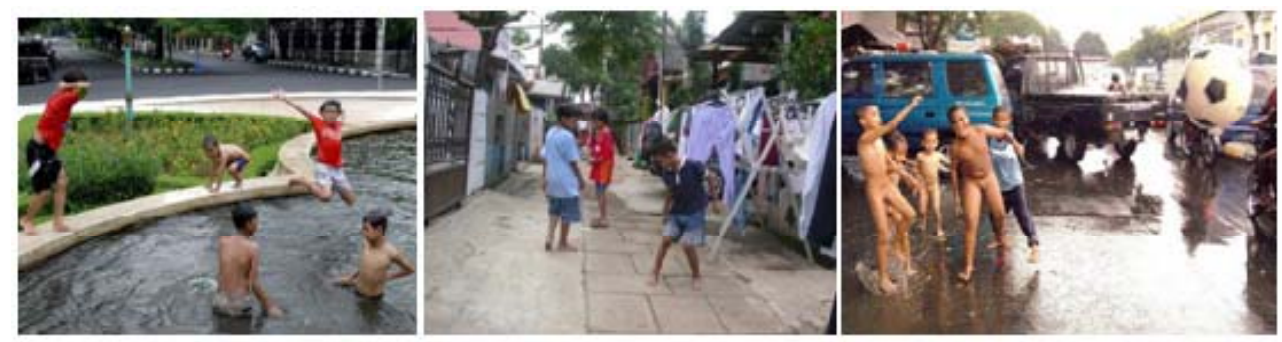

Gambar 1. Tempat bermain yang tidak sesuai. 


\section{Bermain dan Ruang Bermain: antara Psikologi dan Arsitektur}

Baru-baru ini, 31 Mei 2011, Universitas Atmajaya Jogjakarta mengadakan sebuah seminar nasional bertajuk SCAN, Sustainable Culture Architecture and Nature. Apa yang menarik dari seminar tersebut? ternyata arsitektur tidak hanya terkait dengan hal-hal fisik, tetapi juga hal-hal non fisik, misalnya psikologi, antropologi, fashion, film dan teknologi. Sebenarnya pengetahuan adanya hubungan antara psikologi dan arsitektur sudah berkembang sejak tahun 1950-an, pada saat seorang arsitek ditugaskan mendesain rumah sakit jiwa (Dedy Halim, 2005)

Bagaimana dengan bermain? Ada banyak pendekatan terkait dengan bermain, baik dari sisi psikologi, antropologi, sosial, budaya dan arsitektur sendiri. Beberapa pakar psikologis memperkenalakan beberapa teori terkait dengan bermain, Sigmund Freud dengan teori Psikonalisis, Jean Piaget, Vigotsky, Jerome Bruner dengan teori Kognitif, Sutton Smith dengan teori Adaptif dan beberapa teori lainnya, intinya adalah bahwa ada hubungan yang erat antara bermain dan perkembangan anak, baik perkembangan psikososialnya maupun kognitifnya (Diana Mutiah, 2010). Sementara itu Huizinga memperkenalkan teori yang mengatakan bahwa bermain adalah budaya. Namun demikian, berdasarkan kajian terdahulu, bermain lebih dipandang sebuah kegiatan yang bersifat joyous 'asyik' dan cheerful 'ceria'. Bermain tidak dipandang sebagai sebuah kegiatan yang bersifat fisik tetapi lebih dipandang sebagai kegiatan berbasis psikis. Fenomena memperlihatkan bahwa bermain yang sebenarnya pada anak bisa terjadi kapan saja, di mana saja, lintas waktu dan lintas tempat, bermain adalah sesuatu yang free 'bebas'.

Dalam kajian arsitektur, bermain lebih dipandang sebagai sebuah aktivitas fisik yang terstruktur yang perlu diwadahi, sebagaimana aktivitas lainnya. Dan bila aktivitas bermain adalah dianggap sebuah masalah, tugas para arsitek adalah mencari solusi dari permasalahan tersebut. Arsitektur yang bertumpu pada tata atur ruang melihat bermain dalam satu siklus kegiatan yang perlu dipahami dari awal hingga akhirnya. Pemikiran ini melahirkan program tentang bermain dan kelak menghasilkan ruang demi ruang sebagai visualisasi dari program tersebut.

Tidak hanya para arsitek, Howard P. Chudacoff (2007), seorang guru besar dibidang American History dan Urban Studies menjelaskan bahwa ada dua hal penting yang terkait dengan bermain yaitu: (1) place, tempat dimana aktivitas bermain dilakukan. Isu keamaman menjadi point utama; (2) things, alat bermain. Isu pengembangan alat bermain menjadi satu hal yang penting. Kedua isu tersebut akhirnya melahirkan ruang-ruang bermain formal yang teratur dan terstruktur.

Dalam ranah arsitektur, ruang menjadi akhir dari sebuah proses berpikir. Namun demikian, keterbatasan pengetahuan menyebabkan penggunaan istilah tempat (place) dan ruang (space) sebagai bentuk apresiasi terhadap sesuatu yang menunjukkan wadah bagi kegiatan manusia, sering bersifat ambigu. Tempat dan ruang bagi kaum awam acap diyakini mempunyai makna yang sama. Syahdan, lihatlah bagaimana mereka bahkan mungkin kita, memberi sebutan bagi wadah anak melakukan kegiatan main dengan ucapan 'ruang bermain' dan tak jarang terucap 'tempat bermain'. Wacana diskusi place dan space sudah ada sejak dahulu, para pemikir Yi Fu Tuan (2003), Cornelis Van De Van (1991), Edward S. Casey (1998) menyampaikan pengetahuan bahwa place dan space mempunyai makna yang berbeda, place tempat terjadinya sesuatu, sementara space sebagai keberadaan tempat itu sendiri.

Terkait dengan ruang, pemahaman ruang terfokus pada ruang yang digunakan anak sebagai tempat bermain. Mngingat perbedaan konsep bermain, akan memungkinkan untuk menghadirkan ruang bermain yang berbeda dari apa yang ada sekarang, di mana ruang bermain adalah ruang yang dipenuhi dengan berbagai alat permainan. Bagi anak ruang bermain lebih dipandang sebagai sebuah wadah bermain yang hadir atas sebuah kesepakatan bersama, ia tidak berwujud dalam bentuk ruangruang yang kaku, statis dan bersifat formal. Ia bisa saja berwujud sebuah ruang diantara susunan kursi atau meja, jalanan depan rumah, drainase, mobil bekas, bahkan area permakaman. Apakah memang 
demikian? penelitian ini akan merekonstruksi ruang sebagaimana yang disampaikan oleh Yi Fu Tuan, Space is Freedom. (Yi Fu Tuan, 2003). Mengingat masih ditemukannya celah-celah kecil yang kelak dapat menyempurnakan konsep ruang yang disampaikan oleh Yi Fu Tuan - yang diyakini belumlah sempurna - dimensi waktu dan batas (border) menjadi hal yang penting dari sebuah kesepakatan membentuk ruang.

\section{Rumusan Masalah}

Sebagaimana yang telah disampaikan di atas, bahwa anak bisa bermain dimana saja dan kapan saja, lintas tempat dan lintas waktu. Menurut pandangan orang dewasa, kalau anak bermain pada ruang bermain formal, itu adalah sesuatu yang wajar. Namun bila ia bermain pada ruang yang tidak semestinya, itu adalah sesuatu yang tidak wajar. Bagaimana dengan anak? apakah ia juga mempunyai pandangan yang sama? Fenomena tersebut menjadi sesuatu yang menarik untuk diketahui, khususnya bila dikaitkan dengan pertanyaan: bagaimana ruang tersebut terbentuk? dan bagaimana ruang yang terbentuk dimaknai sebagai ruang bermain? Pemikiran ini didasari oleh sebuah penelitian yang dilakukan di Canada, A Canadian study concluded that behavior believed to occur in a place is an important component of the place's meaning (Genereux, Ward \& Russell, 1983). Mereka menunjukkan 20 tempat kepada pengamat yang ditanya mengenai: (1) Mengapa orang pergi ke sana? (2) Apa yang membawa mereka ke tempat itu? 3. Kegiatan apa yang mungkin terjadi di sana? (Robert Gifford, 1996).

Pemanfaatan ruang bermain informal sebagai ruang bermain anak memperlihatkan bahwa anak menilai berbeda terhadap sebuah obyek, anak membaca petanda yang berbeda. Dalam hal ini pengetahuan semiotika yang memahami petanda dan penanda dapat digunakan sebagai upaya untuk menjawab hal-hal yang lebih mendalam tentang ketertarikan anak untuk bermain pada satu obyek informal.

\section{Tujuan Penelitian}

Penelitian ini bertujuan untuk: (1) mengetahui konsep ruang, yang akan menguji konsep ruang yang ada dan akan menghasilkan konsep baru tentang ruang; (2) mengetahui konsep ruang bermain, yang akan menguji konsep ruang bermain yang ada dan menghasilkan konsep ruang bermain baru dikaitkan dengan waktu dan batasan; (3) mengetahui model pengelolaan ruang bermain, yang kelak dapat digunakan untuk hal-hal yang bersifat praktis.

\section{METODE}

Pendekatan yang dilakukan untuk menjawab pertanyaan di atas adalah dengan penelitian kualitatif. Metode ini digunakan untuk mengungkap fenomena pemanfaatan ruang yang digunakan anak untuk bermain anak. Selain itu, karena tujuan penelitian ini adalah mengungkap dan memahami sesuatu dibalik fenomena yang sedikitpun belum diketahui (Anselm Strauss dan Juliet Corbin, 2009). Pendekatan kualitatif ini juga dilakukan karena ingin memahami masalah sosial berdasarkan pada penciptaan gambaran holistik lengkap yang dibentuk dengan kata-kata, melaporkan pandangan informan secara terperinci dan disusun dalam sebuah latar ilmiah (John W. Creswell, 2002).

Sementara itu James J. Gibson mengatakan bahwa pendekatan affordances dapat digunakan sebagai pendekatan pada penelitian yang berbasis lingkungan, psikologi dan anak. " The concept of the affordances refers to the fuctionally significant properties of the environment, and provides a psychologically relevant mean to analyze evolving child environment relationships, affordances operationalize the transactional approach". 
Mengingat segala keterbatasan dari pendekatan affordances yang hanya mampu menjawab tentang 'what', diperlukan pendekatan lain yang mampu memahami dan menggali lebih dalam. Pendekatan Semiotika merupakan sebuah pendekatan yang bisa menggali pertanyaan yang bersifat 'Why' dan 'How'.

\section{HASIL DAN PEMBAHASAN}

\section{Ruang, Teritori, Value dan Niche}

Penelitian bermain dan ruang bermain, merupakan penelitian yang berfokus pada ruang. Ruang adalah sesuatu yang diproduksi, baik secara sosial maupun secara fisik. Apa hubungannya antara ruang dan territory? Pastalan dalam Daniel Stokds dan Irmi Altman (1987) menjelaskan bahwa teritori adalah ruang terbatas yang digunakan dan dipertahankan oleh seseorang atau suatu kelompok. Teritori melibatkan identifikasi psikologis dengan suatu tempat yang dilambangkan oleh sikap posesif dan pengaturan objek di daerah tersebut.

Sedikit berbeda dengan Pastalan, Altman dan Haythorn (1967) mengatakan bahwa teritori melibatkan penggunaan eksklusif mutual suatu daerah dan objek oleh orang dan kelompok. Perbedaan ini dimungkinkan mengingat teritori sendiri dapat dipisahkan dalam dua pendekatan yaitu characteristic of the biological approach 'karakteristik pendekatan biologis' dan the organizational benefits of territoriality 'keuntungan organisasi teritorial'.

Bagaimana hubungannya dengan ruang? mengacu pada konsep yang disampaikan oleh Yi Fu Tuan - di mana ruang adalah sebuah kesepakatan - konsep teritori sedikit berbeda, dalam ruang tidak ada unsur defense 'pertahanan', karena ruang bisa hadir kapan saja dan di mana saja. Namun unsur value dari teritori menjadi hal yang dapat digunakan sebagai bagian penting dari ruang, khususnya ruang bermain. Austin and Bates (1974) mengatakan bahwa teritori adalah kepemilikan dari objek dan ruang bernilai/berharga. Apa yang disampaikan oleh Austin and Bates mengindikasikan bahwa antara ruang dan teritori mempunyai kesamaan di dalam hal nilai yang muncul. Nilai merupakan sesuatu yang tidak bisa diukur secara statistik yang hadir dalam bentuk pikiran dan perasaan. Value sendiri mempunyai arti have power over 'memiliki kekuatan lebih dibandingkan yang lain'. Bila dikaitkan dengan ruang bermain, ruang-ruang yang digunakan oleh anak-anak untuk bermain mempunyai kekuatan lebih - dalam hal ini kekuatan dapat diartikan sebagai becomes 'wujud', yaitu proses untuk memujudkan sesuatu. Perwujudan ruang dan teritori, lebih kepada sebuah proses dibandingkan dengan hasil. Pertanyaan yang muncul dari sebuah proses adalah: bagaimana dan upaya untuk menjawab bagaimana. Pendekatan efektif untuk digunakan adalah metode kualitatif, di mana fokus yang dilihat adalah apa dibalik apa. Sementara itu bagi JJ. Gibson, value artikan sebagai niche, dan niche inilah yang merujuk kepada affordances.

\section{Affordances}

Penelitian yang dilakukan oleh beberapa pihak memperlihatkan bahwa ada hubungan yang erat antara lingkungan anak dengan proses belajar, perkembangan sosial dan bermain (Holloway and Valentine, 2000; Matthews et al, 2000; Punch, 2000 dalam Tory Deer, 2006). Sementara itu penelitian lain juga memperlihatkan bagaimana anak mengexplorasi ruang yang ada disekitar mereka sebelum anak mampu untuk berlari dan berjalan. Kemampuan anak untuk mengenali ruang juga dipengaruhi oleh kemampuan untuk memahami skala. Skala didasarkan pada hubungan matematika (rasio) antara tingkat representasi dan bagian dari realitas (Scott Bell, 2006). Proses penguasaan skala lebih kepada kemampuan kognitif. Apakah memang demikian adanya? atau adakah faktor lain yang mempengaruhi anak pada saat memutuskan untuk menggunakan ruang sebagai wadah untuk bermain? Gibson (1986) 
menyatakan bahwa setiap lingkungan mempunyai niche 'kedudukan' yang berbeda, ini pulalah yang membuat setiap mahluk memberikan respon yang berbeda terhadap lingkungan tersebut.

Beberapa penelitian terkait dengan Affordances telah dilakukan oleh beberapa peneliti diantaranya Marketta Kyttä (2003), Muhamad Suhaizan Samsudin (2008), Ellen Beate Hansen Sandseter (2009), Sumaiyah binti Othman dan Ismail bin Said (2010), Ismail Said (2010). Penelitian ini umumnya memperlihatkan fenomena antara anak bermain dan lingkungan bermainnya. Para peneliti tersebut dengan metode kualitatif memperlihatkan fenomena bermain yang terjadi dari setting yang berbeda. Seperti halnya Sumaiyah yang melihat setting cul de sac sebagai ruang bermain, Ismail Said melihat melihat setting nature sebagai ruang bermain. Dalam implementasi praktisnya, affordances memiliki beberapa tingkatan, yaitu: (1) affordances yang dirasakan; (2) affordances yang dimanfaatkan; (3) affordances yang dibentuk. Kemampuan anak untuk memahami lingkungan sangat dipengaruhi oleh faktor individual dan sosiokultural.

Gibson menejelaskan bahwa ada empat hal yang menjadikan sesuatu objek memiliki affordances kepada manusia: (1) media; (2) zat/bahan; (3) permukaan dan tata letak; (4) objek. Bila dikaitkan kepada anak-anak, empat hal ini penting sebagai acuan penelitian. Penelitian yang berbasis affordances juga lebih dianggap sebagai hal yang sangat terkait dengan persepsi, dalam hal ini adalah persepsi lingkungan. Persepsi sendiri mempunyai hubungan yang erat dengan sensasi. Dedy Halim dalam bukunya Psikologi Arsitektur mengatakan bahwa persepsi adalah proses dimana seseorang mempunyai informasi dari lingkungan sekitar. Persepsi adalah sesuatu hal yang aktif. Paul A. Bell (1978) dalam Joyce Laurens, (2005) mengatakan bahwa persepsi bukanlah sekedar penginderaan, persepsi dikatakan sebagai penafsiran pengalaman. Konsep tersebut dikategorikan sebagai teori persepsi yang konvensional. Sementara itu pendekatan ekologis - pendekatan berdasarkan informasi - inilah yang dikembangkan oleh J. Gibson, yang mengatakan bahwa seorrang individu tidaklah menciptakan makna dari apa yang diinderakannya. Ssesungguhnya makna itu telah terkandung dalam stimulus itu sendiri dan tersedia untuk organism yang menyerapnya (Joyce Laurens, 2005). Persepsi terjadi secara spontan dan langsung, jadi bersifat holistic, spontanitas terjadi karena manusia selalu mengeksplorasi lingkungannya, dalam ekslplorasi itu manusia melibatkan setiap objek yang ada dalam lingkungannya dan setiap obyek menonjolkan sifat-sifatnya yang khas untuk organism tersebut, penampilan makna ini disebutnya affordances.

Gibson dalam Paul A Bell et al (2001) juga menjelaskan bahwa affordances melibatkan persepsi fungsinya ekologis relevan dari lingkungan. Melihat affordances lingkungan adalah melihat bagaimana seseorang dapat berinteraksi dengan lingkungan. Melalui persepsi affordances suatu organisme dapat menemukan niche di lingkungannya. Niche sendiri mempunyai arti mould 'memberi bentuk'. Bila dikaitkan dengan bermain dan ruang bermain, setiap ruang yang dibentuk oleh anak mempunyai niche yang berbeda, dan niche inilah yang menjadikan ruang tersebut memiliki affordances bagi anak. Salah satu penelitian yang berbasis affordances dikembangkan oleh Marketta Kytta (2003). Penelitian yang dilakukan oleh Kytta ini berhasil mengkategorikan affordances untuk anak-anak dan lingkungan. Kytta berhasil meletakan dasar affordances taxonomy untuk studi tentang affordances luar ruangan pada usia 5 - 12 tahun.

\section{Semiotika}

Ferdinand de Saussure, seorang filsuf (dalam Marcel Danesi, 2004) menjelaskan bahwa 'tanda' merupakan struktur biner, yaitu struktur yang terdiri dari dua bagian: bagian fisik yang disebut penanda dan bagian konseptual yang disebut petanda. Sebagai penanda, ruang memiliki sifat membuat tanda yang membedakan. 'Tanda' sendiri mempunyai arti 'batas', yaitu mempunyai batasan teritori tertentu; menyatakan teritori tertentu. Jadi, jelaslah sebagai penanda, Snyder menyatakan bahwa ruang mempunyai batas teritori yang jelas. Selain itu sebagaimana yang disampaikan oleh Saussure, ruang juga memiliki petanda, yang berarti mempunyai indikasi yang membuatnya berbeda dengan yang lain. Pemahaman ruang secara fisik diperjelas dengan pemikiran Max Jammer (1993) yang mengatakan: (1) 
perluasan bukanlan atribut yang membedakan; (2) ruang itu nyata, memiliki atribut nyata, 3. ruang adalah karakter ilahi. Pemahaman Max memperjelas konsep yang disampaikan oleh Snyder bahwa benda yang menjadi lambang dapat dijadikan sebagai penanda.

Bila dikaitkan dengan penelitian ini, Timan (1994) menjelaskan bahwa struktur kode, tanda dan simbol membentuk semiotika kelompok lingkungan dasar, semua elemen secara individual menyampaikan pesan untuk anak-anak tentang penggunaan ruang seharusnya. Bagaimana dan apa yang mereka harus lakukan. Apa yang disampaikan oleh Timan membuktikan bahwa setiap elemen memberi makna tersendiri bagi anak, pengetahuan semiotika ini memungkinkan pemahaman lebih dalam tentang ruang bermain dan mengapa anak-anak menggunakan ruang tersebut.

\section{Penelitian Terkait}

Penelitian tentang Bermain dan Ruang Bermain sudah dilakukan oleh beberapa peneliti sebelumnya, baik dalam bentuk penelitian biasa, maupun penelitian yang berbasis disertasi. Dengan mengacu kepada beberapa penelitian berikut ini diperoleh beberapa hal yang bisa digunakan sebagai acuan bagi penelitian lanjutan.

\section{Penelitian I}

Affordances for Risky Play in Preschool: The Importance of Features in the Play Environment 'Affordances untuk Permainan Beresiko Prasekolah: Pentingnya Fitur-fitur dalam Lingkungan Bermain' (2009) oleh Ellen Beate Hansen Sandseter

Penelitian ini memperlihatkan hubungan antara lingkungan bermain dengan kemungkinan terjadinya resiko kecelakaan pada saat bermain, khususnya pada anak-anak usia prasekolah. Penelitian memperlihatkan bahwa lingkungan bermain yang ada di ordinary preschool sama dengan yang ada di traditional playground (Lee categories). Sementara itu nature preschool playground sama dengan nature playground (Lee categories). Kedua playground tersebut beresiko pada saat bermain. Lingkungan ordinary preschool lebih aman dibandingkan dengan nature playground karena ordinary preschool mempunyai pagar yang membatasi anak bermain. Bila dilihat dari alat permainan yang ada - dengan segala kemungkinan terjadinya resiko pada saat bermain - anak tidak merespon tersebut sebagai sebuah ketakutan untuk bermain.

Penelitian ini juga memperlihatkan bahwa lingkungan bermain yang natural memberi variasi kegiatan fisik lebih baik dan banyak dibandingkan dengan lingkungan bermain standar. Lingkungan bermain alami juga mempunyai tantangan bermain pada anak. Temuan lain adalah lingkungan bermain alami tidak memiliki frekwensi resiko bermain yang tinggi, namun tetap mempunyai resiko bermain.

Metode penelitian menggunakan metode kualitatif dengan dua prasekolah yang berbeda (ordinary preschool playground dan nature playground). Penelitian ini dilakukan dengan cara: (1) observasi; (2) rekaman video; (3) wawancara dengan anak dan guru. Penelitian ini dilakukan dengan mendata lingkungan bermain, seperti alat permainan, vegetasi, dan permukaan tempat bermain.

\section{Penelitian II}

Affordances of Culdesac in Urban Neighborhoods as Play Spaces for Middle Childhood Children 'Affordances Jalan Buntu di Lingkungan Perkotaan sebagai Ruang Bermain untuk Anak-anak' (2010) oleh Sumaiyah binti Othman dan Ismail bin Said

Penelitian ini mengacu pada teori Kytta terkait dengan tingkat affordances yang dibagi ke dalam tiga kategori: perceived 'dirasakan', utilized 'digunakan', dan shaped ‘dibentuk'. Dari 
penelitian ditemukan beberapa hal. Pertama, permainan di jalan buntu dapat dibagi menjadi tiga yaitu: (1) permainan dengan alat; (2) aktifitas pasif; (3) permainan yang memiliki aturan di ruang beraspal/beton atau ruang hijau. Kedua, anak lebih suka bermain dengan latar belakang natural/ alami karena mereka dapat memanfaatkan elemen yang ada (tumbuhan dan hewan) sebagai alat permainan. Ketiga, jalan buntu dengan model yang memiliki bentuk seperti pulau ditengahnya lebih diminati anak dibandingkan dengan yang keseluruhannya di aspal/beton karena mereka bisa menggunakan 'pulau' itu untuk arena bermain juga. Keempat, ruang sempit dan beraspal/beton tetap dapat digunakan anakanak untuk bermain seperti jalan-jalan, berlari, skipping, bermain badminton, bercanda dengan teman, mengobrol, membuat keramaian, menjalin pertemanan, dan melarikan diri sejenak dari para pengasuh.

Penelitian ini dilakukan dengan metode kualitatif pada dua model jalan buntu di dua perumahan berbeda. Pemilihan lokasi ini lebih dikarenakan oleh kedekatan peneliti dengan objek survey. Penelitian dilakukan dengan beberapa tahapan: (1) melakukuan pendekatan kepada anak; (2) membawa anak peneliti untuk ikut serta bermain dengan anak-anak yang tinggal di lokasi perumahan tersebut; tujuannya untuk mendapatkan setting alamiah pada saat penelitian dilakukan; (3) melakukan pendekatan kepada orang tua, untuk meminta ijin wawancara kepada anak-anak mereka. Selain halhal tersebut, peneliti juga melakukan wawancara terstruktur kepada anak-anak dengan panduan kuesioner dan melakukan pengamatan pada jam-jam tertentu.

\section{Penelitian III \\ Affordances of Nearby Forest and Orchard on Children's Performance 'Affordances Lingkungan Hutan Hijau dan Taman Buah berdasarkan Perilaku Anak’ (2010) oleh Ismail Said}

Penelitian ini bertujuan untuk melihat affordances dari hutan hijau dan taman buah terdekat berdasarkan pengalaman anak-anak dan remaja dengan elemen natural. Ada tiga indikator yang dilihat, yaitu aspek: (1) penampilan/peragaan; (2) penjelajahan; (3) produktivitas (Chawla and Heft, 2002). Untuk Level of Affordances, yang dilakukan oleh responden dikelompokan menjadi 3 affordances (kytta, 2003) yaitu: perceived 'dirasakan', utilized 'digunakan' dan shaped 'dibentuk'. Terlihat bahwa ada 62 aktifitas yang digunakan/dipakai, 30 aktifitas dirasakan, dan 6 dibentuk/dibuat. Untuk taxonomy of affordances, ada empat elemen yang disenangi oleh anak-anak, yaitu: (1) air (sebanyak 25 aktivitas); (2) vegetasi (sebanyak 22 aktivitas); (3) menggenggam (sebanyak 12 aktivitas); (4) social (sebanyak 9 aktivitas). Untuk type of affordances, ada 94 affordances positif dan 4 affordances negatif.

Lingkungan alami (natural environment) adalah tempat yang baik bagi anak untuk melakukan aktivitas bermain dan menyalurkan kegiatan fisik. Lingkungan hutan hijau (nearby forest) merupakan salah satu tempat bagi anak untuk mememahami lingkungan alam, mengasah keingintahuan mereka, melakukan kreativitas dengan membuat alat permainan dari bahan alami, dan meningkatkan kegiatan fisik.

\section{Penelitan IV \\ Children's Perceptions of the Use of Public Open Space for Active Free Play 'Persepsi Anak tentang Penggunaan Ruang Terbuka Umum untuk Aktivitas Bermain' (2007) oleh Jenny Veitch, Jo Salmon, dan Kylie Ball}

Tujuan dari Penelitian ini adalah ingin mengetahui beberapa hal. Pertama, apa yang anak-anak rasakan saat bermain di ruang terbuka umum. Hasil memperlihatkan bahwa public open space (POS) users 'pengguna ruang terbuka umum' datang bermain karena menyenangkan, dapat berlari, aktif bergerak, bermain dengan teman dan keluarga. Bermain bola, naik sepeda dan bermain lainnya. Anak menyenangi setting lingkungan alami. Sedangkan non-POS users menggunakan ruang bermain tidak terlalu sering. Alasan mereka relatif sama dengan POS users. Sedangkan anak dari status sosial bawah dan menengah pergi ke taman karena bosan berada di rumah. 
Selanjutnya yang ingin diketahui adalah penghalang untuk menggunakan ruang terbuka umum. Bagi POS users alat permainan yang ada membosankan dan tidak mempunyai tantangan, khususnya mereka yang berusia 8-12 tahun. Alat permainan terkesan hanya untuk anak usia hingga enam tahun saja. Selain itu alasan lain adalah seringnya terjadi penggertakan/aksi preman dari anak yang lebih tua. Sedangkan non POS users bosan dengan alat permainan yang ada, tidak menawarkan tantangan. Alasan lainnya adalah kesibukan setelah sekolah (mengerjakan PR dan les) serta keamanan menuju tempat bermain yang tidak kondusif. Faktor yang memotivasi anak untuk bermain juga yang ingin ditelusuri dalam penelitian ini. POS users akan termotivasi bila tempat bermain (1) menyediakan permainan yang menantang secara fisik, (2) menyediakan alat permainan yang menarik, (3) menyediakan tempat untuk bermain sepeda, bola dan skateboard, (4) dekat dengan rumah dan (5) banyak dikunjungi anak sesusia mereka.

Penelitian ini menggunakan metode kualitatif dengan populasi informan 132 anak sekolah dasar di Victoria, Australia. Usia informan 6-12 tahun dari 3 golongan ekonomi: bawah, menengah, dan atas. Ke-132 anak tersebut dibagi menjadi 26 kelompok FGD, dengan masing-masing anggota 5 orang per FGD. Pemilihan dengan wawancara melalui FGD pada anak mengacu pada penelitian Krueger (1995) dan Hawe (1995). Diyakini dengan FGD, anak akan lebih nyaman untuk menyampaikan pendapat tanpa merasa di ancam atau intimidasi.Selain itu untuk mendapatkan hasil, FGD tersebut dikelompokan menjadi 2 kelompok POS (Public Open Space) Users dan POS non users. Analisis dilakukan dengan ecological model form.

\section{Penelitian V \\ Territorialising the Primary School Playground: Deconstructing the Geography of Playtime 'Pembagian “wilayah” pada Arena Bermain Sekolah Dasar: Dekonstruksi Geografi Waktu Bermain (2005) oleh Sarah Thomson}

Penelitian ini mengacu pada konsep geografi sosial. Penelitian ini ingin melihat bagaimana guru dan pihak lain melakukan percobaan terhadap dua kontrol (ruang dan pergerakan anak pada waktu bermain). Penelitian ini juga menemukan bahwa ruang bermain kontemporer terbatas untuk golongan tertentu dan disesuaikan dengan perintah guru dan pihak-pihak lain yang diberi mandat. Selain itu, penelitian ini juga menemukan bahwa arena bermain di sekolah: (1) terbatas untuk dimasuki; (2) istimewa/khusus; (3) memiliki ketentuan. Penelitian ini juga memperlihatkan bahwa untuk arena yang memiliki status terbatas untuk dimasuki, umumnya diberi batasan yang jelas, baik dalam bentuk pembatasan fisik/ pagar, maupun pembatasan non fisik/ regulasi atau aturan yang diberikan oleh sekolah. Wilayah yang memiliki status istimewa/khusus digunakan oleh anak yang ingin melakukan aktivitas bermain yang baik (tidak gaduh). Sementara itu untuk ruang dengan status memiliki ketentuan, dirancang untuk aktivitas khusus, misalnya football, hopscotch atau lainnya. Penelitian ini menggunakan metode kualitatif pada tiga sekolah berbeda (di kota, pinggiran kota, dan desa).

Pengumpulan data dilakukan dengan observasi dan rekaman pendapat siswa maupun guru. Hasil rekaman dianalisis dengan memperhatikan tone of voice 'nada suara' dan mengelompokkannya dalam tiga kategori: (1) menantang, ramah, dan netral; (2) pitch (tenang, lantang); (3) jenis pendapat (memerintah, netral). Selain itu, analisis dilakukan dengan memperhatikan komentar dari supervisor dan mengelompokkannya dalam group tertentu. Hasil dari analisis memperlihatkan wilayah yang boleh dan tidak boleh digunakan anak untuk bermain.

\section{PENUTUP}

Berdasarkan beberapa penelitian di atas, diperoleh beberapa hal: (1) Penelitian yang berbasis anak, psikologi dan kaitannya dengan lingkungan, umumnya bertujuan untuk melihat fenomena yang 
terjadi. Metode penelitian yang dilakukan adalah metode kualitatif; (2) Analisis data dilakukan dengan berbagai pendekatan, salah satu diantaranya adalah dengan model affordances; (3) Penelitianpenelitian di atas umumnya dilakukan pada ruang bermain outdoor. Selain itu beberapa koreksi dari penelitian-penelitian tersebut: (1) berbasis affordances sehingga hanya mampu bersifat deksriptif; tidak menggali lebih dalam atau eksploratoris sehingga pertanyaan yang dijawab hanya bersifat “apa?” (what?); (2) tidak memperlihatkan bagaimana ruang bermain yang diteliti terbentuk; (3) tidak memperlihatkan bagaimana ruang bermain yang diteliti digunakan, serta dikaitkan dengan waktu dan batasan ruang.

\section{DAFTAR PUSTAKA}

Bell, Scott. (2006). Scale in Children Experience with the Environment, Children and Their Environment. New York: Cambridge University Press.

Binti Othman, S., bin Said, I. (2010). Affordances of Culdesac in Urban Neighborhoods as Play Spaces for Middle Childhood Children. AicE-Bs Proceeding.

Creswell, John W. (2002). Research Design. Jakarta: KIK Press.

Danesi, Marcel. (2004). Messages, Signs and Meanings:A Basic Text Book in Semiotics and Communication Theory. Ontario: Canadian Scholars Press.

Ginting, S. W., Ginting, N. (2002). Dimana Tempat untuk Anak-anak? Jurnal Jelajah, (ed. 1).

Halim, Dedy. (2005). Psikologi Arsitektur. Jakarta: Grasindo.

Kyttä, Marketta. (2002). Children in Outdoor Contexts: Affordances and Independent Mobility in the Assessment of Environmental Child Friendliness. Espoo, Finland: Helsinki University of Technology.

Laurens, Joyce. (2005). Arsitektur dan Perilaku Manusia. Jakarta: Grasindo.

Mutiah, Diana. (2010). Psikologi Bermain Anak Usia Dini. Jakarta: Prenada Media.

Said, Ismail. (2010). Affordances of nearby Forest and Orchard on Children's Performance. AicE-Bs Proceeding. Kuala Lumpur.

Samsudin, Muhamad Suhaizan. (2008). Affordances of Urban and Rural Gardens on Middle Childhood Childrens Performances. Disertasi S3. Malaysia: UTM.

Sandseter, Ellen Beate Hansen. (2009). Affordances for Risky Play in Preschool: The Importance of Features in the Play environment. Early Childhood Education Journal.

Stokds, D., Altman, I. (1987). Hand Book of Environmental Psychology. New York: John Wiley and Sons.

Strauss, A., Corbin, J. (2009). Dasar-dasar Penelitian Kualitatif. Yogjakarta: Pustaka Pelajar.

Yi Fu Tuan. (2003). Space and Place: the Perspective of Experience. Minnesota: University of Minnesota Press. 